\title{
Application of Focus Group Interviews for Business Curriculum Development in Higher Education
}

Ines Dužević

Faculty of Economics and Business - Zagreb

Email: iduzevic@efzg.hr

Helena Miloloža

Faculty of Economics and Business - Zagreb

Email:hmiloloza@efzg.hr

Mia Delić

Faculty of Economics and Business - Zagreb

Email:mdelic@efzg.hr

Doi:10.5901/mjss.2014.v5n13p229

\begin{abstract}
This study emphasises the importance of business community feedback in the process of business curriculum design. In the turbulent business environment, higher education institutions must regularly evaluate and update their curriculum to respond to the emerging business needs. Focus group interviews with representatives from the business community are used to explore possibilities for the improvement of the business curriculum. Moreover, the study analyses the mismatch between graduates' competencies and business community needs and requirements. Our results suggest that employing focus group interviews is a valuable method of gaining more insight into relationships between business community expectations and academic community approach to the processes of curriculum design and teaching. A set of guidelines is provided for the effective conduct of focus group interviews as part of the business curriculum development in the higher education.
\end{abstract}

Keywords: quality improvement, business curriculum development, graduate competency, focus group interview, Croatia

\section{Introduction}

The creation and transmission of knowledge are two main functions of higher education system. To sustain the highly competitive market, higher education institutions (HEls) must regularly evaluate and update their curriculum. According to Tam (2014), international trends in higher education show a shift away from the faculty-oriented model towards learningbased model that focuses on what students know and can actually do. Reputable and successful HEls are putting the professional competencies and employability of graduates in the center of the higher-education transformation process.

Youth unemployment is a major issue for the Croatian government. According to the Croatian Employment Service, the registered unemployment rate was 20.2\% in 2013 (Barić, 2014). There is a large proportion (13.7\%) of young people, aged between 25 and 29 , who are unemployed, and this proportion increased by $4.4 \%$ in the last year. The rate of unemployment of people with higher-education degree ranged between $5.1 \%$ (for the graduates from the first Bologna cycle) and $6.4 \%$ (for the second and third cycle graduates). However, the highest increase in unemployment rate was recorded for people with bachelor's degree, which increased by $14.9 \%$ in the last year.

Increased unemployment caused a dramatic change in the demand on higher education graduates. Employers are now seeking graduates who are both highly skilled and have the appropriate academic qualification to fill positions in their organizations (Daud et al., 2011). Graduates are expected to bring the competencies needed to solve complex problems with them, instead of acquiring them over a long period of practice (Steiner \& Laws, 2006). HEls, and business schools and universities in particular, should align their curriculum with professional competencies and employability of graduates. HEls' capability in creating unique curriculum that produces competitive workforce enhances the branding of the institution, which becomes a marketing tool for the institution to attract student enrolment and generate revenue (Daud et al., 2011).

The aim of this paper is to analyse the gap between the business graduates' professional competencies and the requirements of the business community. Furthermore, the study seeks to identify possible improvements in the 
curriculum and teaching methods that will enable fulfilment of business community needs. Focus group interviews with business community representatives were used to determine their needs and requirements, and to identify possible improvement activities. The results of the study provide valuable guidelines for the management of HEls in driving quality improvements.

\section{Literature Review}

Under the conditions of democratization, variability, and innovation in higher education, the educational competence of college students becomes one of the most important factors of the quality of education (Lyz', 2012). Transformation from faculty-oriented towards learning-oriented and student-centered model is needed. This includes orientation towards students' learning outcomes and more personal interactions between faculty and students. A great emphasis is on students' outcomes and on what students are expected to be able to do at the end of the learning experience (Tam, 2014). HEls must find a way to overcome the contradictions between the requirements on quality, innovative approaches to training and the fact that most students are not prepared for such training (Lyż, 2012). To respond to increased customer requirements, HEls should offer students a broader variety of channels of access to knowledge (García-Aracil \& Van der Velden, 2008; Jurše \& Tominac, 2008). The curriculum should be developed to stimulate students' abilities to succeed in the labor market.

The modes of teaching and learning used during studies are crucial for graduates to develop specific competencies (Vila et al., 2012). The curriculum could also be transformed into a skills-based curriculum which means that detailed handbooks of skills' expectations for each program of study could be created so that teaching staff can have access to a common framework for implementing and assessing the curriculum integration of graduate skills and attributes (Panagiotakopoulos, 2012). HEls should enable students to transfer theoretical knowledge to concrete action and to develop graduates who are capable of learning, managing, and distributing knowledge within networks in the surrounding world (Martensen \& Grønholdt, 2009). To achieve this goal, the management of the HEI and the faculty should develop skills-based curriculum that would provide students with required knowledge and skills.

According to Lyz'(2012): "educational competence can be looked at as a fully formed set of qualities that make it possible for students to choose and implement their own educational trajectory and master their chosen educational program, in a way that is independent, deliberate, and effective". Jurše \& Tominac (2008) divided competencies into subject-related competencies that include specific knowledge of a study field, and generic competencies related to shared attributes which are general to all fields. The graduate's competencies consist of four main dimensions: knowledge, skills, abilities, and personal characteristics (Daud et al., 2011; Noe \& Hollenbeck, 2007). Knowledge is divided into tacit and explicit knowledge. Skills refer to the graduate's abilities to perform a job well. It can be divided into technical or hard skills and behavioural or soft skills. Ability is the graduate's capacity to perform job-related tasks. Personal characteristics include openness, conscientiousness, extroversion, agreeableness, and emotional stability (Robbins \& Judge, 2009).

Employers continually complain that graduates from HEls are unable to meet their expectations. As a result of these major employment market-led pressures, HEls are forced to consider incorporating market-oriented professional competencies among their graduates that require continuous input and long-term alliances established between HEIs and the industry (Daud et al., 2011). The employability of graduates depends on their knowledge, skills, abilities, and personal characteristics. Better-educated individuals are more productive (Vila et al., 2012). Thus, employers want a graduate who is equipped with interactive, personal, and generic skills (Daud et al., 2011; Harvey, 2000; Urtasun \& Núñez, 2012). An ideal worker is skilled and motivated, and is likely to suggest ideas, is able to perform complex problem-solving tasks, and makes decisions (Raybould \& Sheedy, 2005; Urtasun \& Núñez, 2012).

Higher education can make individuals employable and improve their productivity and income-earning opportunities (Panagiotakopoulos, 2012). The use of proactive teaching and learning modes promotes the acquisition of graduates' competencies (Vila et al., 2012). HEls should start developing curriculum with proper evaluation of the relevant professional competencies of graduates (Jurše \& Tominac, 2008; Tam, 2014). Learning outcomes should clearly specify which skills and knowledge are the most important in a program or course. HEls also need to specify what students need to do to achieve defined learning outcomes. According to Tam (2014): "it is no longer enough for designers and teachers to be competent in their discipline; they are required to create, develop, and manage stimulating learning environments, using a variety of resources, methods, and technologies, including assessment resources in order to deepen and enrich student learning". These new competency needs require innovation of curriculum to enable development of new study programs and learning approaches, and improve existing study programs (Martensen \& Grønholdt, 2009). The innovation of curriculum could be implemented using the Quality Function Deployment (QFD) 
method. Gonzalez et al. (2011) found that the QFD approach provides an objective way of designing curriculum and including a set of expectations generated by the market coupled with benchmarking and team analysis. Moreover, HEls need to closely collaborate with industry practitioners to obtain information about current industry expectations of graduates, to design or modify curriculum, and to enhance graduate performance in the working environment (Daud et al., 2011; Morley, 2001).

\section{Research Method}

Focus groups provide deeper understanding of a specific issue and provide insight into how people think and perceive the issue. According to Brits and Du Plessis (2006), focus groups have the potential to gain more insight into and adding more depth to quantitative findings during quality management. Results from focus groups provide quality-assurance practitioners useful and valuable insight into quality-improvement possibilities.

For the purpose of this study, a focus group was organized, composed of 12 relevant representatives from the business community. Participants were employers of various economic fields. Three participants represented small employers who employ economists with a wide range of knowledge and other participants were top managers of large companies who need economists with specialized knowledge in a particular field of the economy. The focus group included representatives from both the service sector and industry sector.

Based on their experiences, observations, and thoughts, we have tried to identify the differences in learning outcomes and behaviours of students according to existing programs of study in relation to the real needs and expectations of the labour market. The aim was to determine in what way the gap between the available competencies and real needs can be reduced. The study of personal and professional competence of graduates was composed of four main areas: knowledge, skills, abilities, and personal characteristics of students who graduated from the Faculty of Economics and Business, University of Zagreb (FEB Zagreb).

\section{Analysis and Results}

In the European Higher Education Area, it is evident that a number of changes are aimed at developing highly qualified personnel to address the needs of the economy. To increase the employability of graduates, it is necessary to provide students with a wider range of professional and personal competencies. We organized a focus group composed of 12 relevant representatives of employers, with the assumption that many competencies that students should acquire by the end of their study and that would facilitate the transition to the business environment do not serve the needs of the labor market.

The focus group answered three main questions:

1. How do you assess knowledge, skills, abilities, and personal characteristics of graduates from FEB Zagreb?

2. Which specific knowledge, skills, abilities, and personal characteristics of FEB Zagreb graduates are satisfying and which are dissatisfying?

3. What changes would you recommend to the management of FEB Zagreb regarding study programs and teaching methods in order to meet your needs and requirements?

Regarding the assessment of the skills and competencies of graduates of the FEB Zagreb, all participants unanimously agreed that most graduates do not possess the necessary knowledge, skills, abilities, and personal characteristics necessary for inclusion in the work environment. Previous studies also found that there is mismatch between graduates' competencies and employers' needs (García-Aracil \& Van der Velden, 2008; Martensen \& Grønholdt, 2009; Panagiotakopoulos, 2012). There is a lack of basic knowledge in the field, lack of commitment and basic business skills. One of the key problems in the process of testing a candidate for the job is related to the personal characteristics of graduates and with their inability to cope with stressful situations and set requirements due to lack of necessary expertise. Another issue is a lack of commitment to the job and lack of willingness to actively participate in the assignments, individual and/or team work. Therefore, employers usually invest several years of quality training work with graduates to enable them and for them to be part of the company's satisfactory operation. Unfortunately, at present, where the market is extremely dynamic with turbulent changes daily, that is often impossible. Therefore, in the absence of available time and faced with an unsatisfactory supply of young economists at the labor market, managers opt for an older population with work experience.

Despite the many negative experiences, they pointed out that there are $20 \%$ of graduates who fulfill their requirements. These are brilliant young people who are aware of the great expectations and intense competition, and who continually invest in themselves and their knowledge, show interest and willingness to changes, and relatively 
quickly succeed to become assimilated into a new work environment.

Daud et al. (2011) conducted a focus group meeting with managers to define what employers' expect regarding graduates' competencies. Based on the managers' suggestions, competencies were divided in four dimensions: knowledge, skills, abilities, and personal characteristics. This study used these dimensions to examine the expectations and perceptions of Croatian managers about FEB Zagreb graduates.

For the positive characteristics of graduates, members of the focus group highlighted the existence of a perception of what they expect from the working environment. In addition, one of the participants pointed out the presence of good elementary knowledge of FEB's graduates compared with graduates from reputable foreign HEls.

Most of the knowledge, skills, abilities, and personal characteristics are dissatisfying. Regarding graduates' knowledge, participants pointed out the lack of basic knowledge in the field and inability to interconnect possessed knowledge from different courses. For example, one participant explained that graduates in the field of accounting did not know how to interpret data from the financial statements of the company. Moreover, graduates are not familiar with the current situation in the society and economy. According to the results of other studies, knowledge, and especially fieldrelated knowledge and the ability to apply knowledge to real-life problems, is very important (Daud et al., 2011; Jurše \& Tominac, 2008; Steiner \& Laws, 2006).

Both hard and soft skills are very important for employers (Daud et al., 2011). The most important skills include capability to establish good relationships and actively participate in group work, capability to solve situational problems, and with high level of technical skills (Jurše \& Tominac, 2008; Raybould \& Sheedy, 2005; Steiner \& Laws, 2006). In Croatian higher education context, graduates' skills, both hard and soft, are also dissatisfying. There is insufficient knowledge about basic business communication and lack of technical skills. There are evident technical problems related to the use of computer, problems in communication such as compiling official letter and formal e-mail message, and the method of business communication within the company and/or with the clients. Presentation skills, ability to clearly express their own opinions and attitudes as well as the capability of negotiating are not at a high level. According to the experiences of one focus group participant, $40 \%$ of graduates fail on the initial test of cognitive knowledge and skills when applying for job. For the other $60 \%$, half of the graduates fail in the second round of testing because of the lack of knowledge in the field, insufficient practical knowledge, poor communication skills or insufficient knowledge of foreign languages.

Graduates' abilities include intellectual and physical abilities. Regarding physical abilities, participants pointed out the graduates' inability to cope with work pressure, to confront problems effectively, and to display pro-activeness. From intellectual abilities, the most dissatisfying elements are the inability to solve current problems at the job, and to make effective decisions. According to Raybould and Sheedy (2005), graduates must show evidence of having the ability to cope with uncertainty, and the ability to work under pressure.

Key concerns regarding graduates' personal characteristics also stated were the lack of motivation and the necessity of awakening interest in active involvement and new work challenges. Many young people do not have the commitment and are not as dedicated at the beginning of a new job. Aside from the absence of entrepreneurial spirit and pro-activeness, they also lack the willingness to accept risks and do not have much international exposure due to mobilization disability and unwillingness to change. Among other things, the biggest problem is the drawback on working habits that hamper the efficient functioning of an organization. Daud et al. (2011) found that the most important competencies include the following personal characteristics: extrovert personality, open personality, emotionally stable personality, and conscientious personality. Furthermore, Raybould and Sheedy (2005) pointed out the importance of readiness to explore and create opportunities, self-confidence, and self-management.

According to the opinion of the members of the focus group, it is necessary to introduce a mandatory practice based on active mentoring and constant work with students. The practice should be organized through partnership with the business community to achieve best results. Callanan and Benzing (2004) pointed out that students that participate in internships and gain practical experience before graduation perform better in their professional careers. A crucial drawback is the lack of professional practice for students whose study is based on learning theory without a clear understanding of the learned subject matter and thus, the inherent inability to connect elements from seemingly different economic fields. To avoid this, it is necessary to work on a more comprehensive connecting and networking between all courses and departments at the FEB Zagreb and to achieve uniformity of terms so that students are capable of relating the material through all their years of study. Moreover, one participant highlighted the need to re-examine the model of conducting exams in a way that assignments are related to specific business problems and not theoretical problems only. This could be done in partnership with the business community representatives who can provide concrete business problems to the academic staff. Daud et al. (2011) also stressed the importance of creating a strong alliance between HEls and industries to produce a competitive workforce. 
One participant's recommendation was an emphasis on students' mobility and greater connectivity with foreign institutions. Recognizing the problem of lack of awareness, participants agreed that the FEB Zagreb should certainly invest more effort in marketing activities to inform all potential students about the positive practices and various programs, and projects and workshops performed at the FEB Zagreb.

Participants also highlighted the need to encourage and prepare students for entrepreneurship and minimize, if not eliminate, the reluctance to accept risk, lack of courage, and ignorance of entrepreneurial opportunities. Recent studies show that entrepreneurship education promotes spirit of entrepreneurship among students and enhances their innovation skills (lacobucci \& Micozzi, 2012; Varblane \& Mets, 2010). According to Varblane and Mets (2010) study, Croatia and Slovenia have good coverage of teaching entrepreneurship in HEls, compared with other countries in the region. However, practice-oriented training in entrepreneurship is limited and the number of entrepreneurship centers is small (Varblane \& Mets, 2010).

Placing greater emphasis on specific case studies was suggested, and organizing a large number of practical workshops through which students would be encouraged and prepared for entrepreneurship. The focus group expressed a great interest in assisting and participating in workshops by way of giving concrete case studies and data. Participation in research projects or problem-based learning and group assignments has a very strong influence on the development of student capability and innovativeness (Vila et al., 2012).

Faced with graduate economists fearful of public speaking, uncertain in themselves, and who lack communication skills, one of the recommendations was the introduction of compulsory presentations by students during class. This would teach them about formal communication and develop their ability to present their own ideas. In this way, students will be forced to be more involved in curricular and extra-curricular activities which would also increase their interest for each course. Academic staff has the main responsibility. They must motivate students and stimulate their interest in the courses they teach. They should motivate students to engage more in different curricular and extra-curricular activities. To improve the graduates' competencies, HEls could raise the number of hours of lecture-hall work, check class attendance, and hold midterm exams (Lyz', 2012).

The results of this study showed that employing focus group is a valuable method of gaining more insight into relationships between business community expectations and academic community approach in the process of curriculum design. However, the study is not without limitations. The study uses business community representatives' perceptions that could be influenced by personal and subjective factors. Our results are based on the perceptions from Croatian managers and could not be generalized to other populations.

\section{Conclusion}

Dynamic market changes in the higher education have led to the introduction of learning-oriented higher education. Increased competitiveness and higher expectations of customers forced HEls to re-examine their quality and to focus more on learning outcomes and the employability of graduates. This is especially important in countries with high youth unemployment rate, such as Croatia. HEls must regularly evaluate and update their curriculum to provide competent and employable graduates.

The curriculum design process should start with analysis of the needs and expectations of all relevant stakeholders, including both students and employers. In this study, we used a focus group with representatives from the business community to identify key graduates' competencies that are the most important for employers. Moreover, the focus group provided valuable and useful insights into the possibilities of quality-improvement initiatives that may enhance student's learning outcomes and enable their employability after graduation.

A fundamental issue in Croatian higher education system lies in many years of acquiring general knowledge only without aligning students according to their qualities, as well as insufficient individual approach during education. It resulted in the lack of interest in acquiring professional and practical knowledge and pursuing higher education only to acquire a diploma. Accordingly, HEl's management must make the effort to produce students whose knowledge and skills acquired during their educational experiences will enable easier employment and lead to better performance in their future jobs.

HEl's management must empower their academic staff to constantly improve their teaching methods and update course content to deliver high- quality education to students. Academic staff also needs to motivate and encourage students to engage more in different curricular and extra-curricular activities, and to stimulate their interest in the study field. Furthermore, HEls must cooperate with the business community, using their feedback in the process of curriculum (re)design, organizing workshops and research projects, and creating partnerships. The results of this study provide useful guidelines for the HEl's management in decision making about managing HEI, designing study programs, and 
implementing teaching improvements.

\section{References}

Barić, M. (ed.) (2014).Yearly Statistics Bulletin.Zagreb: Croatian Employment Service.

Brits, H., \& Du Plessis, L. (2006). Application of focus group interviews for quality management: An action research project. System Practice and Action Research, 20, 117-126.

Callanan, G. and Benzing, C. (2004). Assessing the role of internships in the career-oriented employment of graduating college students.Education and Training, 46(2), 82-89.

Daud, S., Abidin, N., \& Mazuin Sapuan, N. (2011). Enhancing university business curriculum using an importance-performance approach: A case study of the business management faculty of a university in Malaysia. International Journal of Educational Management, 25(6), 545-569.

García-Aracil, A., \& Van der Velden, R. (2008). Competencies for young European higher education graduates: labour market mismatches and their payoffs. Higher Education, 55, 219-239.

Gonzalez, M.E., Quesada, G., Mueller, J., \& Mueller, R.D. (2011). International business curriculum design: identifying the voice of the customer using QFD.International Journal of Education in Business, 4(1), 6-29.

Harvey, L. (2000). New realities: the relationship between higher education and employment.Tertiary Education and Management, 6(1), 3-17.

lacobucci, D., \& Micozzi, A. (2012). Entrepreneurship education in Italian universities: trend, situation and opportunities.Education + Training, 54(8/9), 673-696.

Jurše, M., \& Tominac, P.(2008). Professional competences of graduates as a labour market mechanism for aligning business school curriculum reform with the Bologna Declaration Principles.Management, 13(1), 17-36.

Lyz`, N.A. (2012). The educational competence of college students as a factor of the quality of higher education. Russian Education and Society, 54(6), 80-95.

Martensen, A., \& Grønholdt, L. (2009). Quality in higher education: linking graduates' competencies and employers' needs.International Journal of Quality and Service Sciences, 1(1), 67-77.

Morley, L. (2001). Producing new workers: quality, equality and employability in higher education.Quality in Higher Education, 7(2), 131138.

Noe, R.A., \& Hollenbeck, J. (2007). Fundamental of Human Resource Management. New York: McGraw-Hill.

Panagiotakopoulos, A.(2012). Employability skills development in Greek higher education institutions (HEIs). Higher Education, Skills and Work-Based Learning, 2(2), 141-150.

Raybould, J., \& Sheedy, V. (2005). Are graduates equipped with the right skills in the employability stakes?.Industrial and Commercial Training, 37(5), 259-263.

Robbins, S.P., \& Judge, T.A. (2009). Organizational Behaviour.(13. ed.). New Jersey: Pearson Education.

Steiner, G., \& Laws, D. (2006). How appropriate are two established concepts from higher education for solving complex real-world problems? International Journal of Sustainability in Higher Education, 7(3), 323-340.

Tam, M. (2014). Outcomes-based approach to quality assessment and curriculum improvement in higher education. Quality Assurance in Education, 22(2), 158-168.

Urtasun, A., \& Núñez, I. (2012). Work-based competences and careers prospects: a study of Spanish employees. Personnel Review, $41(4), 428-449$.

Varblane, U., \& Mets, T. (2010).Entrepreneurship education in the higher education institutions (HEIs) of post-communist European countries.Journal of Enterprising Communities: People and Places in the Global Economy, 4(3), 204-219.

Vila, L.E., Perez, P.J., \& Morillas, F.G. (2012). Higher education and the development of competencies for innovation in the workplace.Management Decision, 50(9), 1634-1648. 